similar for the 109 patients who died more than a week after the last visit and were discovered to have treatable conditions.

Those who died received more treatment than did survivors (table II). Seventeen $(31 \%)$ of those who died within a week were receiving chemotherapy and 43 $(80 \%)$ hormone treatment, and the findings in those who died after more than a week were similar. The prevalence of chemotherapy among those who died within a week was 2.6 times that among those alive with recurrent disease (31\% $v 12 \%)$. Generally, the intensity of treatment for cancer increased the closer the patients were to death. In addition, of all those who died, two thirds were receiving analgesics and two fifths were receiving psychoactive drugs.

\section{Discussion}

Patients in the terminal stages of breast cancer were being intensively treated for both their disease and their symptoms. Indeed, they were being more intensively treated for their disease than those patients who were not in the terminal stages but may have had recurrent disease. Many of the patients in the terminal stages were also being investigated for other conditions but only three of 54 would have been likely to benefit.

It is difficult to predict when a patient is in the terminal stages of a disease, but our analysis of the notes suggested that death had been adequately predicted. The case notes showed that 53 of the 54 terminally ill patients had been assessed to have progressive disease that responded poorly to treatment. Treatment may have been intensified in the hope of extending the patient's life. It is well established, however, that treatment does not extend the average survival at this stage, ${ }^{2-5}$ so that if some patients are having their lives extended others must be having their lives shortened. Sometimes treatment may be given for palliation. This is especially true of radiotherapy, but in our study a higher proportion of women who died than survived were being given chemotherapy, which often has side effects even when drugs are taken to ameliorate those effects. Such palliation might be more easily and less expensively achieved with pain killing or psychoactive drugs.

Our findings suggest that more attention was being paid to the cancer than to the patient. More emphasis on the care and comfort of patients in the terminal stages of cancer than on continuing diagnostic activity and treatment of the cancer would increase the patient's quality of life and conserve hospital resources.

1 Timothy AR. Cost versus benefit in non-surgical management of patients with cancer. Br.Med f 1988;297:471-2.

2 Powels TJ, Coombes RC, Smith IE, Jones JM, Ford HT. Failure of chemotherapy to prolong survival in a group of patients with metastatic breast cancer. Lancet $1980 ; 1: 580-2$

3 Bonadonna G, Valagussa P. Chemotherapy of breast cancer: current views and results. Int f Rad Oncol Biol Phys 1982;9:279-97.

4 Todd M, Shoag M, Cadman E. Survival of women with metastatic breast cancer at Yale from 1920 to 1980. $\mathcal{F}$ Clin Oncol 1983;1:406-8.

Patel JK, Nemoto $T$, Vezeridis $M$, et al. Does more intense palliative treatmen improve overall survival in metastatic breast cancer patients? Cancer 1986:57:567-70

Accepted 10 Octwber 1988
Cancer Research

Campaign Laboratories, Department of Cancer

Studies and Department of Social Medicine,

University of Birmingham, Medical School, Birmingham B15 2TJ

L S Young, PHD, research fellow

I S Bevan, BSC, technician

$M$ A Johnson, PHD, research

fellow

P I Blomfield, MRCOG, research fellow C B J Woodman, MRCOG, lecturer

Department of Pathology, University of Bristol, Medical School, Bristol BS8 1TH

T Bromidge, BSC, technician N J Maitland, PHD, lecturer

Correspondence to: $\mathrm{Dr}$ Young.

BrMed f 1989;298:14-8.

\title{
The polymerase chain reaction: a new epidemiological tool for investigating cervical human papillomavirus infection
}

\author{
L S Young, I S Bevan, M A Johnson, P I Blomfield, T Bromidge, N J Maitland, \\ C B J Woodman
}

\begin{abstract}
The polymerase chain reaction is an in vitro method for primer directed enzymatic amplification of specific target DNA sequences. The technique was used to detect human papillomavirus types 11 and 16 simultaneously in cellular DNA recovered from cervical smears in 38 women referred for colposcopy to evaluate cytological abnormality and 10 women with no history of cytological abnormality. The polymerase chain reaction was shown to be both specific and sensitive in detecting human papillomavirus DNA such that a single human papillomavirus molecule was detected in $10^{5}$ cells. Of the 38 women with cytological abnormality, all were positive for human papillomavirus on testing with the polymerase chain reaction; 36 were infected with human papillomavirus type 16 and 22 dually infected with human papillomavirus types 11 and 16 . Seven of the 10 women with no cytological abnormality were also infected with human papillomavirus type 11 or 16 .

The use of the polymerase chain reaction will facilitate epidemiological investigation of the aetiological role of human papillomavirus in cervical neoplasia. This preliminary analysis suggests that the prevalence of human papillomavirus infection is greater than previously reported.
\end{abstract}

\section{Introduction}

Though the precise aetiology of cervical neoplasia is unknown, the epidemiological profile of the disease makes it almost certain that oncogenesis is the result of sexual transmission of an infectious agent. ${ }^{22}$ Cytological, histological, and immunohistochemical studies have shown an association between human papillomavirus infection and cervical neoplasia. ${ }^{3-5}$ This has been confirmed by the cloning of various human papillomavirus genotypes from genital lesions (human papillomavirus types $6,11,16,18,31,33$, and 35 ) and the subsequent detection of these virus types in intraepithelial and invasive cervical lesions. ${ }^{6.14}$ Human papillomavirus types 6 and 11 are associated predominantly with benign lesions (condylomas) or low grade dysplasias whereas types 16 and 18 occur in most invasive cervical carcinomas ${ }^{14}$; human papillomavirus types 31,33 , and 35 have been less commonly found in carcinomatous tissue..$^{11-14}$

Recent reports have cast doubt on the role of human papillomavirus in cervical cancer; human papillomavirus type 16 DNA has been detected in normal cervical tissue, ${ }^{15-21}$ and the results of one study have suggested that the apparent association between this virus type and cervical neoplasia disappears after adjustment for age. ${ }^{19}$ One of the main factors contributing to the difficulties in obtaining clear epidemiological evidence of the role of human papillomavirus in cervical neoplasia is the lack of an appropriate method for assessing type specific human papillomavirus in fection. The techniques of Southern, dot-blot, and "filter in situ" hybridisation have problems of sensitivity and specificity, particularly when DNA extracted from cervical smears is examined. ${ }^{22}$ Thus 
new or improved methodologies for assessing human papillomavirus infection are essential if valid epidemiological studies are to be performed.

The polymerase chain reaction is an in vitro method for primer directed enzymatic amplification of specific target DNA sequences. ${ }^{23}$ The technique can amplify a specific target sequence present only once in a sample of $10^{6}-10^{6}$ cells. We aimed at establishing whether the technique could be used to detect human papillomavirus types 11 and 16 in cellular DNA extracted from cervical smears.

\section{Subjects and methods}

Study population-We studied 48 women: 38 women aged 19-63 (median 29) in one group and 10 women aged 20-45 (27) in another. The 38 women in the first group had been referred to the colposcopy clinics at Birmingham and Midland Hospital for Women for investigation of cytological abnormality. In every case two cytological samples were taken from the cervical transformation zone after colposcopic examination of the cervix and before the application of acetic acid. The first of these smears was sent for routine cytological examination and the second, taken with the same spatula, was placed in $10 \mathrm{ml}$ of cold phosphate buffered saline for subsequent DNA extraction in the department of cancer studies by the standard sodium dodecyl sulphate-proteinase $\mathrm{K}$ lysis technique. A colposcopically directed punch biopsy specimen was then taken from the area of greatest abnormality for histological

TABLE 1-Sequences of oligonucleotide primers

\begin{tabular}{llcc}
\hline $\begin{array}{l}\text { Human } \\
\text { papillomavirus } \\
\text { type }\end{array}$ & Sequence $\left(5^{\prime} \rightarrow 3^{\prime}\right)$ & $\begin{array}{c}\text { Genomic } \\
\text { location }\end{array}$ & $\begin{array}{c}\text { Size of amplified } \\
\text { product (base } \\
\text { pairs) }\end{array}$ \\
\hline 11 & A CGCAGAGATATATGCATATG & $221-240$ & 90 \\
16 & B AGTTCTAAGCAACAGGCACA & $291-301$ & 120 \\
18 & A TCAAAAGCCACTGTGTCCTG & $421-440$ & 100 \\
& B CGTGTTCTTGATGATCTGCA & $521-540$ & \\
\hline
\end{tabular}

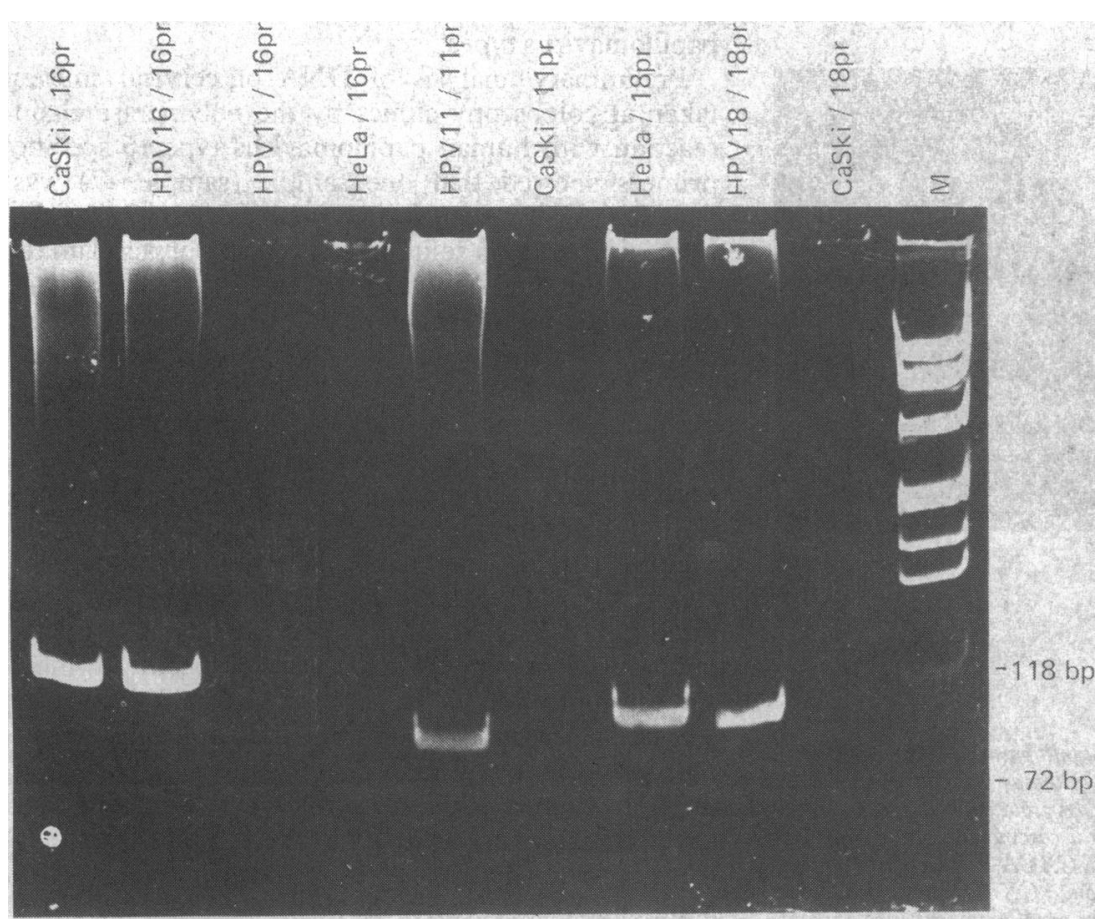

FIG 1 -Comparison and specificity of amplification products of human papillomavirus types 16,11 , and 18 obtained by polvmerase chain reaction. Polvacrylamide gel electrophoresis and ethidium bromide staining of products obtained with specific oligonucleotide primers and cellular DNA $(50 \mathrm{ng})$ from CaSki or HeL a cells or plasmid DNA (20 ng containing human papillomavirus type 16, type 11, or type 18 DNA). $11 \mathrm{pr}$, $16 \mathrm{pr}$ and $18 \mathrm{pr}=$ Specific primers for human papillomavirus types 11,16 , and 18, respectively; $H P V=$ human papillomavirus; $M=D N A$ size markers assessment. The severity of cervical intraepithelial neoplasia was graded as cervical intraepithelial neoplasia 1,2, or 3, according to the criteria of Ferenczy. ${ }^{24}$ A histological diagnosis of human papillomavirus infection was recorded if koilocytes were present. The 10 women in the second group were attending either gynaecology outpatient clinics for investigation of benign disorders unrelated to cervical neoplasia or family planning clinics for contraceptive advice. Two cervical smears were taken in every case and treated as above.

Polymerase chain reaction-Various concentrations of purified plasmid cloned DNA (of human papillomavirus types 11,16 , and 18); DNA from CaSki or HeLa cells; or $0.5 \mu \mathrm{g}$ DNA from cervical cells were amplified in a $100 \mu \mathrm{l}$ reaction mixture containing $(a) 16.6 \mathrm{mmol} / \mathrm{l}$ ammonium sulphate, $6.7 \mathrm{mmol} / \mathrm{l}$ magnesium chloride, and $67 \mathrm{mmol} / \mathrm{l}$ trometamol $(\mathrm{pH} 8.8) ;($ b) $1.5 \mathrm{mmol} / \mathrm{l}$ each of deoxyadenosine triphosphate, deoxycytosine triphosphate, deoxyguanosine triphosphate, and deoxythymidine triphosphate; (c) $10 \mathrm{mmol} / \mathrm{l} 2$-mercaptoethanol and $10 \%(\mathrm{v} / \mathrm{v})$ dimethyl sulphoxide; $(d) 200$ $\mu \mathrm{g} / \mathrm{l}$ gelatin, (e) $1 \mu \mathrm{mol} / \mathrm{l}$ human papillomavirus type specific oligonucleotide primer; and $(f) 2$ units thermostable DNA polymerase (Taq polymerase). The samples were overlaid with mineral oil, denatured for 7 minutes at $94^{\circ} \mathrm{C}$, and subjected to 30 cycles of amplification. A cycle represents $(a)$ primer extension for two minutes at $70^{\circ} \mathrm{C},(b)$ denaturation for one minute at $92^{\circ} \mathrm{C}$, and $(c)$ reannealing for two minutes at room temperature followed by primer extension as in (a). The requirement for additional Taq polymerase during the amplification varied with the source and batch of enzyme. After the last cycle samples were incubated for $5-10$ minutes at $70^{\circ} \mathrm{C} ; 15 \mu 1$ of the reaction mixture was analysed by electrophoresis on $12 \%(\mathrm{w} / \mathrm{v})$ polyacrylamide gels, and the amplified products were visualised by staining with ethidium bromide. When no bands were visible the remaining sample was precipitated with ethanol and reanalysed by polyacrylamide gel electrophoresis. Southern blotting of the amplified samples was performed as described ${ }^{18}$ with an oligonucleotide probe of 40 nucleotides to the internal portion of the amplified sequence.

\section{Results}

VALIDATION OF THE POLYMERASE CHAIN REACTION

Selective amplification of a target DNA sequence with the polymerase chain reaction is achieved through repeated cycles of denaturation of the DNA, annealing with two oligonucleotide primers complementary to regions flanking the target sequence, and extension of the primers with Taq polymerase. In applying this technique to detecting human papillomavirus types 11 , 16 , and 18 we designed oligonucleotide primers complementary to sequences in the E6 region of these human papillomavirus types (table I). We chose the primers so that target sequences of different sizes would be amplified according to human papillomavirus type. Cell lines containing human papillomavirus type 16 (CaSki containing about 400-500 copies of human papillomavirus DNA per cell) or type 18 ( HeLa containing about $10-50$ copies per cell) and plasmids containing cloned human papillomavirus DNA or DNA isolated from tumour biopsy specimens were used to test the validity of the polymerase chain reaction with these primers. Figure 1 shows that the sizes of the amplified products were as predicted from the design of the primers - that is, 123 base pairs for CaSki cells and human papillomavirus type 16,90 base pairs for human papillomavirus type 11 , and 100 base pairs for HeLa cells and human papillomavirus type 18. The specificity of the reaction was further confirmed 
by the absence of bands when human papillomavirus type specific primers were used in reactions containing human papillomavirus DNA of a different type - that is, with human papillomavirus type 16 specific primers and DNA from human papillomavirus type 11 or HeLa cells, human papillomavirus type 11 specific primers and DNA from CaSki cells, or human papillomavirus type 18 specific primers with DNA from CaSki cells (fig 1). Furthermore, no bands were seen when these primers were used in polymerase chain reactions with DNA isolated from cell lines that do not contain human papillomavirus (that is, in B cell and neuroblastoma cell lines) or with DNA isolated from fetal tissue (cervix, skin, and liver). Southern blot analysis of the amplified products with appropriate human papillomavirus probes labelled. with phosphorus-32 further confirmed the specificity of the polymerase chain reaction (fig 2), as did diagnostic restriction digests of the amplified products (data not shown).

TABLE II-Prevalence of human papillomavirus types 11 and 16 in women with and without possible cervical cytological abnormality

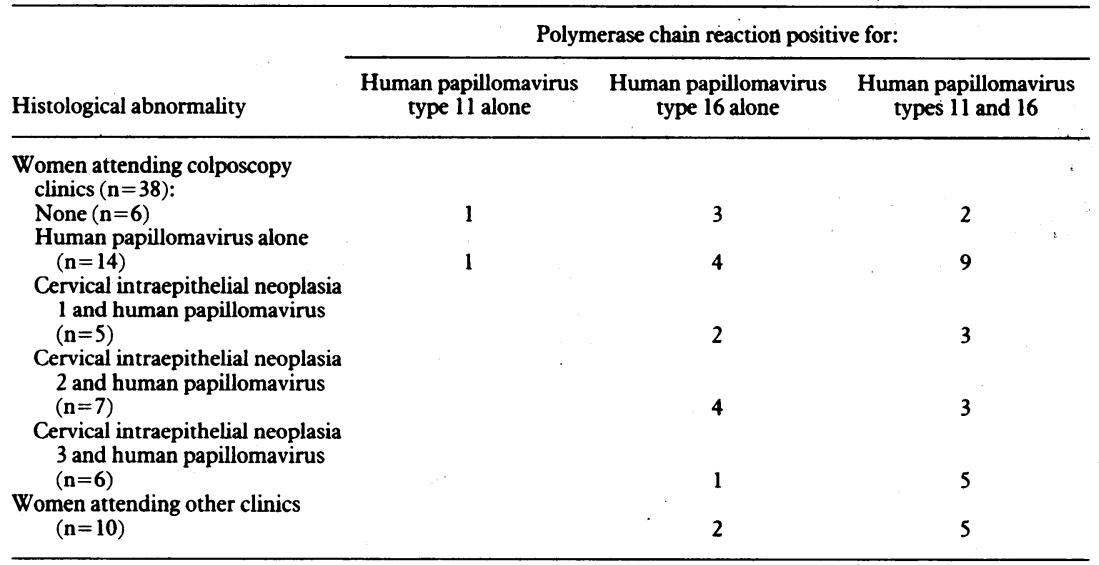

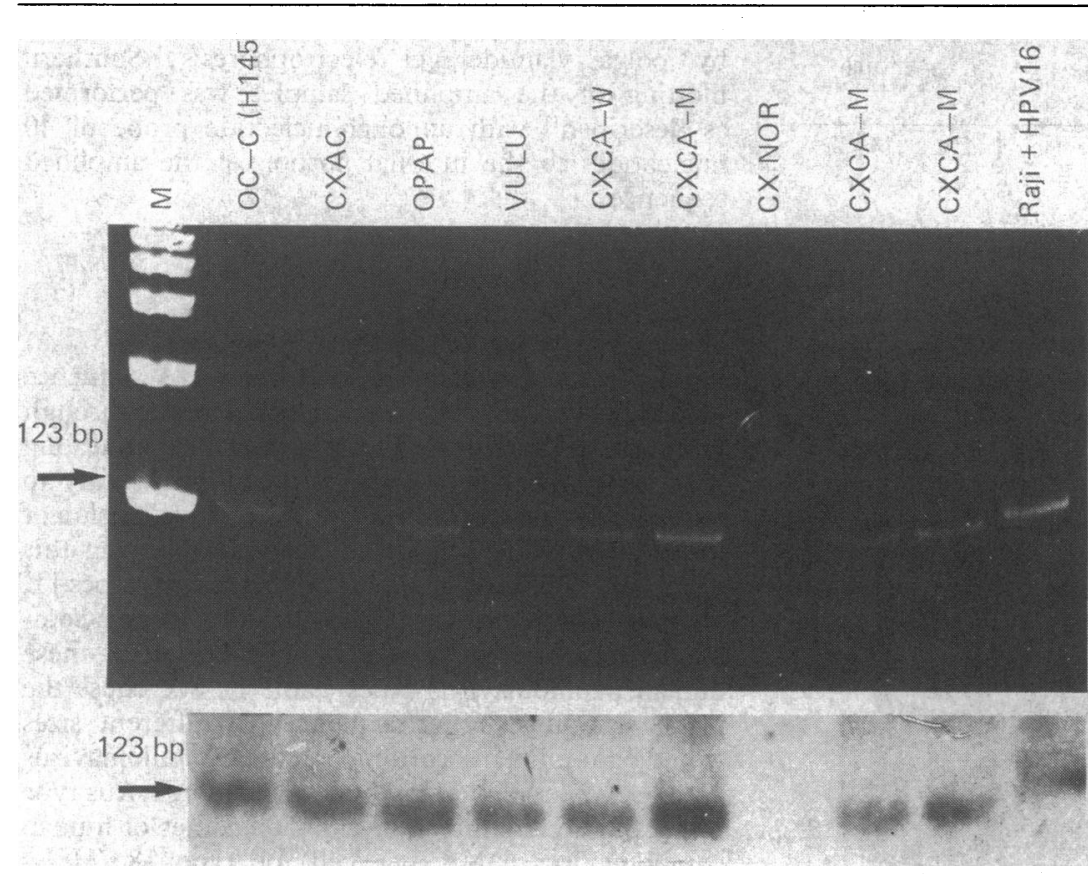

FIG 2-Amplification of DNA from human tissue with human papillomavirus type 16 specific oligonucleotide primers by polymerase chain reaction. Top panel: polyacrylamide gel electrophoresis and ethidium bromide staining of products of polymerase chain reaction on DNA isolated from various biopsy specimens and cell cultures. $M=D N A$ size markers, $O C-C(H 145)=$ oral carcinoma culture, $C X A C=$ human acanthoma, OPAP =oral papilloma, VULU =vulval leucoplakia, $C X C A-W=$ well differentiated cervical carcinoma, $C X C A-M=$ moderately differentiated cervical carcinoma, $C X N O R=$ normal cervix, Raji + HPV 16=positive control with one copy per cell of cloned human papillomavirus type 16 DNA added to DNA from Burkitt's lymphoma cell line negative for human papillomavirus type 16, $b p=b a s e$ pair. Lower panel: Southern blot of amplified polymerase chain reaction products from gel confirming specificity for human papillomavirus type 16 DNA. (Amplified products from gel were immobilised on Genescreen membrane (DuPont) and hybridised with oligonucleotide probe of 40 nucleotides end labelled with phosphorus-32 and taken from region between the two human papillomavirus type 16 E6 region primers)

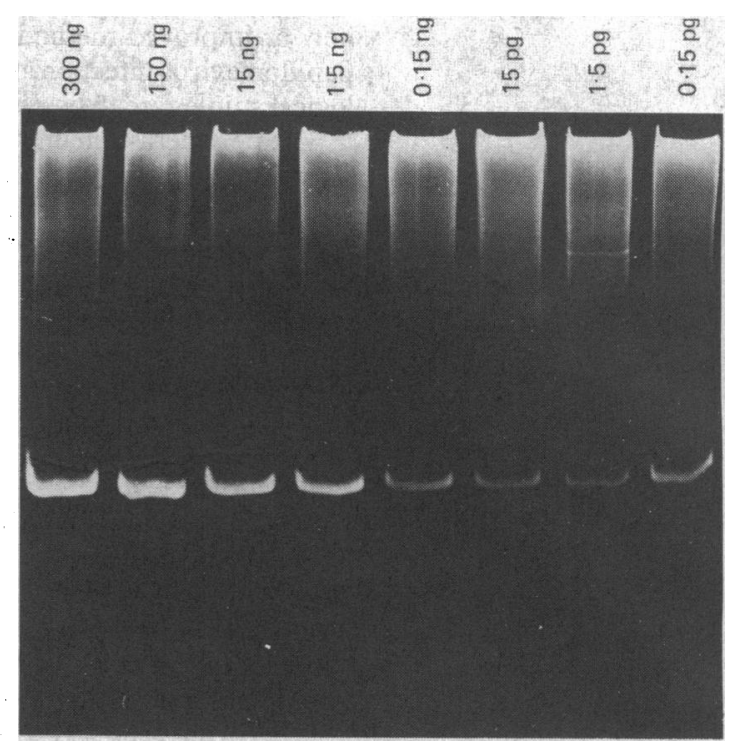

FIG 3-Sensitivity of amplification by polymerase chain reaction with human papillomavirus type 16 specific oligonucleotide primers and different concentrations of DNA from CaSki cells $(300 \mathrm{ng}-0 \cdot 15 \mathrm{pg})$ diluted in DNA from Raji cells (final DNA concentration $0.5 \mu \mathrm{g}$ )

The sensitivity of the polymerase chain reaction was assessed with various concentrations of either cellular or plasmid DNA containing human papillomavirus DNA. Figure 3 shows the results of one such study using dilutions of DNA from CaSki cells in DNA from the Raji cell line that does not contain human papillomavirus type 16. As little as $0 \cdot 15 \mathrm{pg}$ of DNA from CaSki cells could be detected by direct visualisation of gel stained with ethidium bromide. Assuming that CaSki cells contain 500 copies of human papillomavirus type 16 DNA per haploid genome and that a diploid cell contains $7 \mathrm{pg}$ DNA, this implies that the polymerase chain reaction can detect around 10 copies of human papillomavirus type 16 DNA without the need for subsequent Southern blotting. With the additional sensitivity afforded by blotting a single copy of human papillomavirus type 16 DNA could be detected. A similar degree of sensitivity has been observed with the polymerase chain reaction for detecting other human papillomavirus types.

Preliminary analysis of DNA of cervical smears taken at colposcopy clinics by the polymerase chain reaction with human papillomavirus type 16 specific primers showed that one sample (sample 47) was negative (fig 4a) even after ethanol precipitation of the remaining reaction solution and repeat polyacrylamide gel electrophoresis. The other samples gave the human papillomavirus 16 specific 120 base pair amplified product, but this band was of varying intensity (fig 4 (top)). Amplification of human papillomavirus type 11 plasmid DNA and DNA in cervical smear samples 38, 43 , and 47 with the human papillomavirus type 11 specific primers gave the predicted 90 base pair band (fig 4 (bottom)). The polymerase chain reaction on a mixture of DNA from CaSki cells and human papillomavirus type 11 plasmid DNA and on cervical smear samples 1,7 , and 87 with a mixture of human papillomavirus type 11 and type 16 specific primers showed both the 90 base pair and 120 base pair amplified products, suggesting that multiple primer reactions can be used for simultaneously detecting different human papillomavirus types. Southern blot analysis further confirmed that the amplified products from cervical smear samples were specific for human papillomavirus (data not shown)

\section{PREVALENCE OF HUMAN PAPILLOMAVIRUS}

Histological examination of the biopsy specimens from the 38 women in the first group showed no ab- 
normality in six cases, human papillomavirus infection alone in 14, and human papillomavirus infection associated with cervical intraepithelial neoplasia in 18 (table II). There were no cases of cervical intraepithelial neoplasia without associated human papillomavirus infection. All 10 women in the other group had had at least two consecutive negative smears; two had three negative repeat smears, and one had four negative repeat smears. Thirty six samples (95\%) from women in the first group were positive for human papillomavirus $16,24(63 \%)$ were positive for human papillomavirus 11 , and $22(58 \%)$ were positive for both. Dual human papillomavirus infection was also seen in the other group, in which seven of 10 samples were positive for human papillomavirus.

\section{Discussion}

The lack of a serological test for human papillomavirus infection together with the inability to cultivate human papillomavirus in vitro has necessitated the development of DNA hybridisation methods to identify subjects infected with the virus. The existing DNA

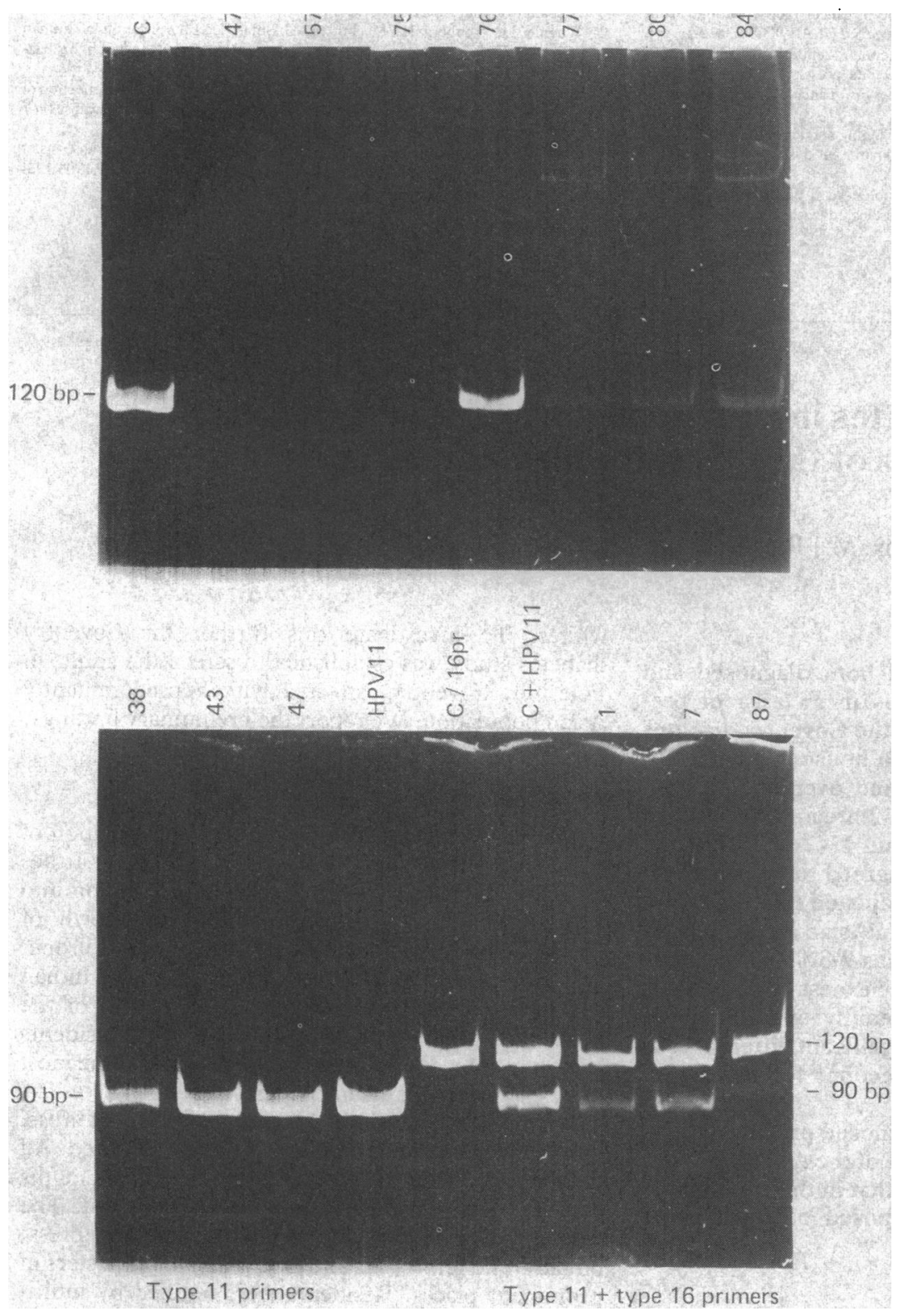

FKG 4-Amplification of DNA isolated from cervical smear. Top: polymerase chain reaction with human papillomavirus type 16 specific primers and DNA from CaSki cells $(C)$ and on $0.5 \mu \mathrm{g}$ DNA from cervical smears (samples 47, 57, 75,76,77, 80, and 84); bottom: polymerase chain reaction with human papillomavirus type 11 specific primers and mixed human papillomavirus type 11 and type 16 specific primers with control DNA (human papillomavirus type 11 plasmid DNA or CaSki cell DNA (C), or both) and $0.5 \mu \mathrm{g}$ DNA from cervical smears (samples $1,7,38,43,47$, and 87) hybridisation techniques, though generally accepted to be the gold standard for diagnosing human papillomavirus infection, have problems of specificity and sensitivity and may underestimate the prevalence of infection. ${ }^{2122} 25$

We report on the validation and application of the polymerase chain reaction in detecting human papillomavirus DNA in cytological samples. The sensitivity of the technique is such that a single molecule of human papillomavirus DNA can be detected in $10^{5}$ cells. Thus the polymerase chain reaction is at least $10^{5}$ fold more sensitive than Southern blotting, in which the detection of less than one copy of viral DNA per haploid cell genome is difficult. The specificity of the polymerase chain reaction is shown by $(a)$ the detection of an amplified band consistent in size with that predicted from the design of the oligonucleotide primers, (b) the absence of amplification with human papillomavirus type specific primers with either cells containing another human papillomavirus type or cellular DNA not containing human papillomavirus DNA, and $(c)$ the confirmation by Southern blotting that the amplified bands were specific for human papillomavirus type. The technique has additional advantages: routine analysis requires only $0.5 \mu \mathrm{g}$ of cellular DNA, simultaneous detection of more than one human papillomavirus type is possible, the test can be completed in a day once the DNA has been extracted, and steps to mechanise the process are already well advanced.

With increasingly widespread application of the polymerase chain reaction many workers are experiencing problems with false positive results due to contamination of either the samples or the primers by DNA. ${ }^{26}$ Thus the advantage of the technique (that is, its exquisite sensitivity) can also be its disadvantage. The problem is easily resolved by careful handling of all DNA samples and by including negative control DNA.

In all women in whom cervical cytology was abnormal human papillomavirus infection was detected by the polymerase chain reaction. The infection was with human papillomavirus type 16 either alone or in association with type 11 but never type 11 infection alone. In the light of previous studies using Southern blotting or in situ hybridisation ${ }^{27-29}$ this prevalence of human papillomavirus infection in cervical intraepithelial neoplasia is not surprising given the greater sensitivity of the polymerase chain reaction. Although the numbers are small, our data do not support the opinion that human papillomavirus type 16 is more likely to be associated with more severely dysplastic lesions. ${ }^{14}$ They do, however, confirm reports suggesting that the prevalence of human papillomavirus infection in normal cervical tissue is greater than previously suspected. ${ }^{18-20}$ Thus we found that 7 women $(70 \%)$ ( $95 \%$ confidence interval $53 \%$ to $98 \%$ ) with no history of cytological abnormality were positive for human papillomavirus type 11 or 16 . Gergely et $a l^{20}$ with a less sensitive technique found that the prevalence of human papillomavirus type 11 or 16 in a similar group of women was $54 \%$ (39\%-7.9\%).

Two recent reports concluded that clear epidemiological evidence supporting an aetiological role for human papillomavirus in cervical neoplasia is still lacking. ${ }^{22} 25$ This deficiency can in part be explained by the absence of a sensitive, specific, and widely applicable test for human papillomavirus infection. The polymerase chain reaction meets many of the requirements of such a test and should greatly facilitate future epidemiological investigations of the oncogenic potential of human papillomavirus in cervical epithelium. We are using the technique in a longitudinal study of young women who have recently become sexually active and will make sequential ob- 
servations on the natural course of cervical intraepithelial neoplasia in relation to human papillomavirus infection.

This research was supported by a grant from the Cancer Research Campaign. We acknowledge the help and guidance of Mr D M Luesley, Mr J A Jordan, Dr C A Meanwell, and Professor E G Knox and thank the Brook Advisory Centre for its cooperation, Dr J Fox for synthesising the oligonucleotides, and Miss D Williams for typing the manuscript. cancer related to current searches for transmissible agents. Cancer Res 1973;33:1353-67

2 Cook GA, Draper GJ. Trends in cervical cancer and carcinoma in situ in Great Britain. Br f Cancer 1984;50:367-75.

3 Reid R, Stanhope R, Herschman VR, et al. Genital warts and cervical cancer. Cancer 1982;50:377-87.

+ Walker PG. Singer A, Dyson JL, Shah KV, To A, Coleman DV. The prevalance of human papillomavirus antigen in patients with cervical prevalance of human papillomavirus antigen in paic

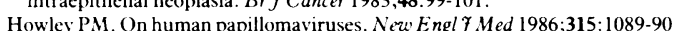

6 De Villiers EM, Gissman L, Zur Hausen H. Molecular cloning of viral DNA from human genital warts. $\mathcal{f}$ Virol 1981;40:932-5.

Gissman L, Zur Hausen H. Partial characterisation of viral DNA from human genital warts (condylomata acuminata). Int f Cancer 1980;29:143-6.

8 Gissman L, Wolnik L, Ikenberg H, Koldorsky V, Schnurch HG, Zur Hausen H. Human papillomavirus types 6 and 11 DNA sequences in genital and laryngeal papillomas and in some cervical cancers. Proc Natl Acad Sci USA 1983;80:560-3.

9 Durst M, Gissman L, Ikenberg H, Zur Hausen H. A papillomavirus DNA from a cervical cancer and its prevalence in cancer biopsy samples from different geographic regions. Proc Natl Acad Sci USA 1983;80:3812-5.

10 Boshart M, Gissman L, Ikenberg H, Kleinheinz A, Schuerlen W, Zur Hausen $\mathrm{H}$. A new type of papillomavirus DNA, its presence in genital cancer H. A new type of papillomavirus DNA, its presence in genital cancer
biopsies and in cell lines derived from cervical cancer. EMBO f 1984;3: biopsies

11 Lorincz. AT, Lancaster WD, Temple GF. Cloning and characterisation of the DNA of a new papillomavirus from a woman with dysplasia of the uterine cervix. F l'irol 1986;58:225-9.

12 Beaudenon S, Kremsdorf D, Croissant O, Jablonska S, Wash-Hobson S, Orth GA. A novel type of papillomavirus associated with genital neoplasias. Nature 1986;321:246-9.
13 Lorincz. AT, Quinn AP, Lancaster WD, Temple GF. A new type of papillomavirus associated with cancer of the uterine cervix. l'irology 1987; 159:187-90.

14 McCance DJ. Human papillomavirus and cancer. Biochim Biophys Acte 1986;283:205-9.

15 Schneider A, Kraus H, Schuhmann R, Gissman L. Papillomavirus infection of the lower genital tract: detection of viral DNA in gynaecological swabs. $\operatorname{Int} \mathcal{F}$ (985:35:443-8.

16 Wickenden C, Steele A, Malcolm ADB, Coleman DV. Screening for wart virus infection in normal and abnormal cervices by DNA hybridisation of cervical crapes. Lancet 1987; i:65-7.

17 Toon PG, Arrand JR, Wilson LP, Sharp DS. Human papillomavirus infection of the uterine cervix of women without cytological signs of neoplasia. Br.Med $f$ $1986 ; 293: 1261-4$

18 Cox MF, Meanwell CA, Maitland NJ, Scully C, Blackledge G, Jordan JA Human papillomavirus type 16 homologous DNA in normal human ectocervix. Lancet 1986;ii:157-8.

19 Meanwell CA, Cox MF, Blackledge G, Maitland NJ. HPV 16 DNA in norma and malignant cervical epithelium: implications for the aetiology and hebaviour of cervical neoplasia. Lancet 1987; : $: 703-7$.

20 Gergely L. Czegledy J, Hernady $Z$. Human papillomavirus frequency in normal cervical tissue, Lancet 1987;ii:513.

21 De Villiers EM, Wagner D, Schneider A, et al. Human papillomavirus infections in women with and without abnormal cervical cytology. Lance 1987;ii: 703-5.

22 Munuz N, Bosch X, Kaldor JM. Does human papillomavirus cause cervical cancer? The state of the epidemiological evidence. Brf Cancer 1988;57:1-5.

23 Saiki RK, Gelfand DH, Stoffel S, et al. Primer-directed enzymatic amplificatio of DNA with a thermostable DNA polymerase. Science 1988;239:487-91.

24 Ferenczy A. Cervical intraepithelial neoplasias. In: Blausen A, ed. Pathology of the female genital tract. New York: Springer-Verlag, 1977:156-77.

25 International Agency for Research on Cancer. Human papillomavirus and cervical cancer. Lancet 1988;i:756-7 (Conference report).

26 Lo Y-MD, Mehal WZ, Fleming KA. False-positive results and the polymerase chain reaction. Lancet 1988 ;ii:679.

27 Wagner D, Ikenberg H, Doehm N, Gissman L. Identification of human papillomavirus in cervical swabs by deoxyribonucleic acid in situ hybridizapapil Obset Gynecol 1984:64:767-72.

28 Schneider A Kraus $\mathrm{H}$, Schuhmann R, Gissman L. Papillomavirus infection of the lower genital tract: detection of viral DNA in gynaecological swabs. Int $\mathcal{7}$ Cancer 1985;35:443-8.

29 Crum CP, Nagai N, Levine R, Silverstein S. In situ hybridization analysis of HPV 16 DNA sequences in early cervical neoplasia. Am J Pathol 1986;123: $174-82$.

(Accepted 27 October 1988)

\title{
Prevalence of diabetes in a predominantly Asian community: preliminary findings of the Coventry diabetes study
}

\author{
D Simmons, D R R Williams, M J Powell
}

\begin{abstract}
To assess the prevalence of both diagnosed and undiagnosed diabetes mellitus in an area of predominantly Asian population the Coventry diabetes study is carrying out house to house screening for diabetes in people aged 20 and over in Foleshill, Coventry. In the first five of 12 areas to be studied 2130 of 2283 Asian $(93.3 \%)$ and 1242 of 1710 white subjects $(72 \cdot 6 \%)$ aged $20-79$ agreed to be screened. The prevalence of diabetes adjusted to 1987 demographic estimates was $11.2 \%$ in Asian men and $8.9 \%$ in Asian women whereas it was $2.8 \%$ in white men and $4.3 \%$ in white women. The excess of diabetes in Asian subjects was predominantly of non-insulindependent diabetes, and no significant differences in body mass were found to account for the higher prevalence.
\end{abstract}

Diabetes had not been diagnosed previously in at least $26 \%$ of the white and $30 \%$ of the Asian diabetics screened, and it is estimated that in this community the condition remains undiagnosed in $42 \%$ of white and $40 \%$ of Asian diabetics.

\section{Introduction}

The Southall diabetes study showed that the prevalence of known diabetes in Asian people was four times that in white people, 'but the proportion of diabetics in whom the condition remains undiagnosed among Asians is unknown and may differ from that among whites. To investigate this further the Coventry diabetes study was established to screen the adults in Foleshill, Coventry, an area with a predominantly Asian population. We report the preliminary findings.

\section{Methods}

The electoral ward of Foleshill has a population of 18500 , of whom 11000 are aged 20 and over. It has traditionally been the area of initial immigration into Coventry: earlier this century from the north of England and from Ireland, then from eastern Europe, and more recently by Asians from either the Indian subcontinent or Africa. More than a quarter of the population is unemployed, and over 2500 residents leave and enter Foleshill each year. It is one of the most underprivileged wards in England and Wales. ${ }^{2}$

For the survey Foleshill was divided into 12 areas, and our results are of the first five areas screened. Al people resident in the area for more than four months each year and aged 20 and over were included. The survey was given extensive publicity in the local press, on radio and television, and by the display of posters in prominent places. Residents were notified by multilanguage leaflets distributed the day before the visit of the reasons for the survey and the expected arrival time of the team. They were visited at home by two of 15 fieldworkers who had been recruited from the local population; half of the fieldworkers could speak an Asian language. The information obtained from the 